\title{
Raising the Quality of Belief
}

Suzhi and the Production of an Elite Protestantism

\section{Cao Nanlai}

\section{OpenEdition \\ Journals}

Édition électronique

URL : http://journals.openedition.org/chinaperspectives/4924

DOI : $10.4000 /$ chinaperspectives.4924

ISSN : 1996-4617

Éditeur

Centre d'étude français sur la Chine contemporaine

Édition imprimée

Date de publication : 31 décembre 2009

ISSN : 2070-3449

\section{Référence électronique}

Cao Nanlai, «Raising the Quality of Belief », China Perspectives [En ligne], 2009/4 | 2009, mis en ligne le 01 décembre 2012, consulté le 28 octobre 2019. URL : http://journals.openedition.org/ chinaperspectives/4924; DOI : 10.4000/chinaperspectives.4924 


\title{
Raising the Quality of Belief
}

\author{
Suzhi and the Production of an Elite Protestantism
}

NANLAI CAO

The paper addresses the changing dynamics of Protestantism in contemporary urban China through the lens of the Christian discourse of quality (suzhi). Linking suzhi with processes of identity and subject formation in the Chinese Protestant community, the paper shows that the religiosity of today's Chinese Protestants is not so much related to acts of spiritual seeking in a state-centred political framework as it is shaped by desires and practices of self-making among neoliberal individuals under rapid marketisation. It also demonstrates that Chinese Protestantism has undergone not just a quantitative increase but also a qualitative change that counters the one-dimensional representation of Christian religiosity in the post-Mao era.

$\mathrm{T}$ he Christian revival is among one of the most remarkable social and cultural changes occurring in China in the post-Mao era. Considered a deep social stigma closely linked to Western imperialism and colonialism half a century ago, Christianity is now increasingly regarded as modern, fashionable, and even coveted among China's urban population, especially the younger generation. ${ }^{(1)}$ Chinese Christians not only hold worship services, prayer meetings, Bible study sessions, Sunday schools, and choir rehearsals but are also actively engaged in the market economy and contributed to the post-Mao modernisation. ${ }^{(2)}$ While the party-state still sets the parameters within which Christians can pursue and promote their faith in the broader society, Christianity, in both popular and official discourse, has been increasingly recognised as a legitimate participant of Chinese modernity and a positive moral force "benefiting a spiritually hungry population that is growing more "individualistic." (3)

Western discourse on Chinese Christianity has been dominated by sensational journalistic accounts of state religious persecution on the one hand, and speculative demographic assessments on the Christian proportion of society on the other. While China historians have contributed a great deal to the understanding of Chinese Christianity today, few social scientists have engaged in fieldwork-based research on contemporary Chinese Christianity and its changing dynamics. ${ }^{(4)}$ Christianity in post-Mao China has been popularly perceived as an alternative reality for people who are spiritual needy and politically disillusioned - an explanation that is too abstract to have any scholarly significance. ${ }^{(5)}$ This paper aims to provide an empirically-grounded, drastically different picture, in which the religiosity of Chinese Protestant Christians is not so much related to acts of spiritual seeking in a state-centred political framework as it is shaped by desires and practices of self-making among neoliberal individuals under rapid marketisation.

My analysis explores this Protestant project of self-making with a focus on the quality (suzhi) discourse among the urban-oriented church community. Suzhi is a keyword in contemporary Chinese life and has structured a wide range of post-Mao socio-political practices. ${ }^{(6)}$ In particular, it has become an overarching term that marks one's sense of selfworth and value in the market economy, and the governing elite views raising the suzhi of China's vast population as vital to the country's overall competitiveness in the era of global capitalism. ${ }^{(7)}$ Likewise, as I argue below, the emerg-

1. Robert Marquand, "In China, Pews are Packed; Beijing is Wary as Christianity Counts up to 90 Million Adherents," Christian Science Monitor, Boston, Mass., 24 December 2003, p. 1.

2. Nanlai Cao, "Christian Entrepreneurs and the Post-Mao State: An Ethnographic Account of Church-State Relations in China's Economic Transition," Sociology of Religion, vol. 68, no. 1, 2007, pp. 45-66; "Boss Christians: The Business of Religion in the 'Wenzhou Model' of Christian Revival," The China Journal, no. 59, 2008, pp. 63-87.

3. Robert Marquand, "China Opens Door to Christianity - of a Patriotic Sort," Christian Science Monitor. Boston, Mass., 8 March 2004, p. 1; see also Alan Hunter and Chan Kim-Kwong, Protestantism in Contemporary China, Cambridge, Cambridge University Press, 1993, p. 265.

4. Daniel Bays, "Chinese Protestant Christianity Today," The China Quarterly, no. 174 2003, pp. 488-504; Ryan Dunch, "Protestant Christianity in China Today: Fragile, Fragmented, Flourishing," in S. Uhalley, Jr., and X. Wu, China and Christianity: Burdened Past, Hopeful Future, Armonk, New York, M. E. Sharpe, 2001, pp. 195-216. On Catholics, see Eriberto P. Lozada Jr., God Aboveground: Catholic Church, Postsocialist State, and Transnational Processes in a Chinese Village, Stanford, Stanford University Press, 2001 Richard Madsen, China's Catholics: Tragedy and Hope in an Emerging Civil Society, Berkeley, University of California Press, 1998.

5. See, for example, David Aikman, Jesus in Beijing, Washington, DC, Regnery Publishing, 2003; Nicholas D. Kristof, "Keeping Faith in China," New York Times, 25 June 2006. pp. 4,13 .

6. Andrew Kipnis, "Suzhi: A Keyword Approach, The China Quarterly, no. 186, 2006, pp. 295-313.

7. Yan Hairong, "Neoliberal Governmentality and Neohumanism: Organizing Suzhi/Value Flow through Labor Recruitment Networks," Cultural Anthropology, vol. 18, no. 4, 2003, pp. 493-523. 
ing Christian discourse of suzhi articulates a sense of urban elite subjectivity and becomes central to the development of the Chinese church in the context of a highly commercialised economy.

To make this point, I have structured the article as follows. I shall first explore the socio-political context in which the Christian discourse of suzhi is made possible, especially in comparison to the resurgence of Chinese popular religion that has been labelled as superstition by both modernist $\mathrm{Chi}$ nese states and Christian orthodoxy for most of the twentieth century. Then I shall explore the suzhi discourse in the post-Mao context of Protestant revival in Wenzhou, one of China's most advanced regional economies. I shall use this case to illustrate how the Christian discourse of suzhi involves simultaneously an expression of elite status in religious terms and the cultural and political use of social power to construct an urban religious identity. This discursive production of identity constitutes a core cultural mechanism of Protestant development in economically advanced urban areas that is distinctively different from that in the economically stagnant rural inland, e.g. Henan Province (known as the Bethlehem of China). Although I lack the space to make a comparative case here, I hope the effort will suggest some new directions in the thinking on this understudied topic.

\section{Contextualising the Christian discourse of suzhi}

The suzhi discourse is a direct outgrowth of the state program of population control and governance. ${ }^{(8)}$ Since the introduction of the one-child policy in the early 1980s, the Chinese government has focused its efforts on reducing the quantity and raising the quality of the population (renkou suzhi). Driven by anxieties over the low suzhi of the Chinese people and the nation's quest for its rightful place in the world, population quality became a key concern for both the party-state and the general public in the 1990s. Under this context, the state project of raising the quality of the population has discursively associated everything that seems to impede China's modernisation with low suzhi and backwardness. Popular religion has been a main target of attack. Ann Anagnost notes the following:

As the reform decade of the 1980s continued, feudal superstition continued as a potent sign of backwardness and, at times, depending on the larger political context, as a powerful marker of social disorder as well. As a sign of backwardness it became caught up in the late 1980s with the project of raising the quality of the people (tigao renminde suzhi). This project extends far beyond a directly eugenics discourse to encompass issues of education and the inculcation of the masses with the requirements of good citizenship. For instance, engaging in popular religious practice would disqualify a peasant household from attaining any of the status markers that designate model households, such as the civilized household (wenminghu) or the Five-Good Family (wuhao jiating ${ }^{(9)}$ ).

There are only five officially-sanctioned religions in China today: Buddhism, Daoism, Protestantism, Catholicism, and Islam. Theoretically illegal, folk or popular religious practices have nevertheless flourished in the Reform Era. ${ }^{(10)}$ The only viable means for popular religious temples to attain legitimacy seems to be refashioning themselves as Daoist or Buddhist organisations. ${ }^{\text {(II) }}$ The assertion of state presence, in the form of either cultural discourse or institutional arrangement, has accompanied the revival of popular religion. As detailed in Adam Chau's research on a popular religious temple in Shaanbei, local religious elites actively channel local resources upward to various local state agencies in exchange for official recognition and protection of their illegal activities, while the local state profits by channelling legitimacy downward. ${ }^{(12)}$ According to Chau, in this "channelling zone," properties of popular religion are considered new sources of revenue by local state agencies and have become a power base for local officials to pursue their growing personal greed and vanity. While these "superstitious" elements of religion have revived in rural China, it should be made clear that, for popular religious activists, this politics of legitimation is a consequence of their illegality and stigmatisation in broader society. Throughout the process of legitimation politics the essentialist state category of superstition imposed on popular religion is not unsettled but reinforced and perpetuated. In this sense, this channelling process is simultaneously a process of illegalisation of popular religion.

8. For an inspiring analysis of the relationships of suzhi to earlier discourses and the contemporary sociopolitical context, see Andrew Kipnis, "Suzhi: A Keyword Approach," art. cit.

9. Ann Anagnost, "Politics of Ritual Displacement," in C. F Keyes, L. Kendall and H. Hardacre, Asian Visions of Authority: Religion and the Modern States of East and Southeast Asia, Honolulu, University of Hawaii Press, 1994, pp. 228-229.

10. For a comprehensive treatment of Chinese popular religious culture and practices entangled with processes of modernity and state-building, see Mayfair Yang, ed. Chinese Religiosities: Afflictions of Modernity and State Formation, Berkeley, University of California Press, 2008.

11. Adam Yuet Chau, Miraculous Response: Doing Popular Religion in Contemporary China, Stanford, Calif., Stanford University Press, 2006.

12. Adam Yuet Chau, Ibid 
The social stigma and illegality attached to popular religion contrasts sharply with a sense of cultural legitimacy and superiority associated with Christianity in today's China. Protestant Christianity, assuming and embodying a fundamental distinction between religion and superstition, can be conveniently tied in with the state project of raising the quality of the people, especially in resisting evil cults and heterodoxy and fending off the impact of popular religion. In her study of rural Wenzhou's ritual communities, Mayfair Yang observes that local officials generally hold a favourable attitude towards Christianity due to its connections with the modern West and its differentiation from popular religion. ${ }^{(13)}$ She quotes one Wenzhou township official saying:

It is different with Christianity, which respects science, and science is even an outgrowth of Christianity. It's different with our own religion. It's backward and teaches people to believe in superstitions, magic, and devils. It tells people that this and that is bad luck. And, religion is used by people as a pretext for making money (pianqian). It's this bad segment of religion that we have to attack. ${ }^{(14)}$

Although unregistered Christian churches continue to face local official opposition and excessive policing in the Reform Era for a variety of reasons (some are clearly not on religious grounds), Christianity has assumed a moral high ground in many urban localities due to its emphasis on spiritual ideology and ethical principles. The Christian rhetoric of morality is often very forceful in celebrating the ultimate, transcendent good. By containing such binary concepts as saved or unsaved, belief or unbelief, good or evil, heaven or hell, it incorporates a language of dominance and power. Furthermore, there is little appreciation for the culture of merit-making that is central to Buddhism. As Richard Madsen points out, in contrast to Christian philosophy that absolutises the notion of goodness (as a quality identified with God), there is no clear distinction between good and evil in either the Confucian tradition or the Daoist classics. ${ }^{(15)}$ The distinction has been profoundly blurred by the Chinese emphasis on li or ritual and social propriety. ${ }^{(16)}$ While goodness is key to achieving good karma for Buddhists, it is not perceived as an ultimate goal. ${ }^{(17)}$ The forceful Christian moral rhetoric lends tremendous power to the self-justification of Christian identity. For many, Christians and non-Christians alike, being Christian means being good. Along this line of reasoning, one's Christian identity will be challenged if certain moral standards are not met. The Christian sense of moral superiority can be traced back to the late nineteen and early twentieth centuries, when the Puritanical Christianity was brought into China by Western missionaries. Protestant belief played an important and visible part in the making of Chinese citizenship and the reform of immoral social practices such as gambling, opiumsmoking, concubinage, child-brides, and prostitution in the early Republican period. ${ }^{(18)}$ Nowadays Christianity is known as a religion that promotes family harmony, and Christians claim a disproportionately high number of "model workers" and low crime rates in their midst. ${ }^{(19)}$ The officially-recognised church has made morality (e.g. honesty, obedience, and restraint) a central theme of sermons and publications, in accordance with its effort to adapt to socialist morality. ${ }^{\left({ }^{20)}\right.}$ Increasingly, Christianity has become an officially recognised source of public morality to complement the state's vision of morality and contribute to social harmony, especially given the prevalence of corruption and inequality in society. Its legitimacy and cultural superiority are further reinforced in the party-state's anti-"evil cult" discourse, which has taken shape since the crackdown on Falun Gong in the late 1990s. ${ }^{(21)}$ In contrast, popular religion, with its emphasis on the materiality of ritual practices, is unlikely to participate in the elite discourse of morality or in the construction of identity communities based on a shared moral language. In domestic Chinese scholarly discourse popular religion has even been blamed for impeding Christianity's development and tainting its image in rural China by making Christianity "low-class, vulgar, and backward" (diji cusu luohou) and unlikely to contribute to China's modernisation. ${ }^{(22)}$ During various anti-superstition campaigns, popular religion was labelled as an evil element in the ideological realm and an unproductive social force. State displacement of popular reli-

13. Mayfair Yang, "Spatial Struggles: Postcolonial Complex, State Disenchantment, and Popular Reappropriation of Space in Rural Southeast China," Journal of Asian Studies no. 63, 2004, pp. 719-755.

14. Mayfair Yang, "Spatial Struggles," art. cit., pp. 745-746.

15. Richard Madsen, Democracy's Dharma: Religious Renaissance and Political Development in Taiwan, Berkeley, University of California Press, 2007, pp. 155-156.

16. On the notion of li, see Robert P. Weller, Alternate Civilities: Democracy and Culture in China and Taiwan, Boulder, Westview Press, 1999, pp. 26-28.

17. Richard Madsen, Democracy's Dharma, op. cit., p. 156.

18. Ryan Dunch, Fuzhou Protestants and the Making of a Modern China, 1857-1927, New Haven and London, Yale University Press, 2001.

19. Alan Hunter and Chan Kim-Kwong, Protestantism in Contemporary China, op. cit., p. 8.

20. Alan Hunter and Chan Kim-Kwong, Ibid., p. 158

21. For an insightful analysis of the state anti-xiejiao discourse, see David A. Palmer, "Heretical Doctrines, Reactionary Secret Societies, Evil Cults: Labeling Heterodoxy in Twentieth-Century China," in Mayfair Yang, Chinese Religiosities, op. cit., pp. 113-134.

22. Gao Shining, "Dangdai zhongguo minjian xinyang dui jidujiao de yingxiang" (The impact of popular religion on Christianity in contemporary China), Religion, no. 3, 20005, p. 56 
gious and ritual practices not only formed an integral part of the violent political campaigns of the Maoist era but has continued in the post-Mao modernisation process. ${ }^{(23)}$

In an important sense the moral and economic agency of the party-state parallels the self-claimed superiority of urban Protestantism. Both place popular religious and ritual activities in the antithetic position of futility and backwardness as a way of constructing their own legitimacy. This resemblance is reminiscent of the relationship of Western missionaries in the nineteenth and early twentieth centuries and the Han Chinese socialist state, both of which celebrated the spirit of Puritanism and represented themselves as a civilising force against China's ethnic minorities. ${ }^{(24)}$ This parallel relationship allows Chinese Protestantism to borrow the legitimacy of state discourse to promote its place in Chinese modernity. However, this is also a contested process in which the state attempts to remake individual subjects and local communities while Chinese believers seek to engage the state on their own terms.

There have been discussions on how to raise the suzhi of preachers, other clergy, lay believers, and even choir conductors in Tianfeng (Heavenly Wind), the official Protestant bimonthly magazine published in cosmopolitan Shanghai and the mouthpiece of the Three-Self Patriotic Movement. Despite their diverse approaches, the urban religious sophisticates all hold the view that as the number of Chinese believers increases, the church ought to be more concerned with the "quality of belief" (xinyang suzhi). One essay entitled "comments on the quality of belief" defines it as a combination of a believer's confidence in God's plan and his/her behaviour and as an overall judgment of a believer's understanding and practice of Christian truth. ${ }^{(25)}$ The preacher's suzhi often is considered key to raising the quality of belief among the entire church, and can include such qualities as a neat and solemn appearance, good work and reputation, a loving heart, serious spiritual pursuit, and cultural knowledge. ${ }^{(26)}$ It is noteworthy that these are all "individually embodied, human qualities" rather than non-human entities. ${ }^{(27)}$ In Christian terms, suzhi are God-given qualities. The Christian suzhi discourse thus distinguishes itself from state discourse by emphasising divine agency and God-human interaction.

In the circles of the Three-Self Patriotic Movement and state-approved seminaries, the project of raising the quality of belief is often juxtaposed with the controversial theological reconstruction movement, which emphasises downplaying the doctrine of "justification by faith" and adapting to socialism. ${ }^{(28)}$ As Bishop Ding Guangxun points out, "The paramount issue (zhong zhong zhi zhong) in the Chinese church's work is to strive to raise the overall quality (zhengti suzhi) of Christians and actively facilitate Christian education reform and promote theological reform among the coworkers." ${ }^{(29)}$ According to Ding, the underlying logic of theological reform is that "a Christian has to be a good citizen first; otherwise he/she cannot be a good Christian." ${ }^{(30)}$ In an essay entitled "How to Raise the Quality of Belief," a pastor from the Nanjing Union Theological Seminary (the only national seminary in China), indicates that the quality of belief has become a central issue with regard to Chinese Protestant citizenship. As he states:

Raising the quality of belief among lay believers, on theological and political levels, is to guide the majority of believers to self-consciously bear a duty of citizenship (gongmin zeren), to stick to the principle of holding loyalty to the motherland and of loving the people, and to take initiatives to understand and support the nation's modernisation enterprise. In other words, we need to actively guide believers to adapt to socialist society. In sum, at this stage to raise the quality of lay believers in the Chinese church is to most effectively explain to the majority of believers the importance and content of the theological reconstruction work. ${ }^{\left({ }^{(1)}\right.}$

With a central concern for the role of Protestantism in the state discourse on socialist modernisation, the theological reconstruction movement is likely to alienate official church leadership from the majority of ordinary Protestants at the local level who tend to insist on an apolitical religious out-

23. Ann Anagnost, "Politics of Ritual Displacement," art. cit, Mayfair Yang, "Spatial Struggles," art. cit.

24. Stevan Harrell, "Introduction: Civilizing Projects and the Reaction to Them," in Stevan Harrell, Cultural Encounters on China's Ethnic Frontiers, Seattle, University of Washington Press, 1995, pp. 3-36.

25. Wang Tianmin, "Mantan xinyang suzhi" (Comments on the quality of belief), Tianfeng, no. 8,2003 , p. 50

26. Guo Sanshun, "Jiangdao renyuan suzhi tan" (On preachers' quality), Tianfeng, no. 1, 1997, pp. 39-40.

27. Andrew Kipnis, "Suzhi: A Keyword Approach," art. cit., p. 297

28. Tian Xiao, "Zengqiang jiaohui suzhi, dizhi yiduan xieshuo (To enhance the quality of the church and resist heterodoxy and evil cults), Tianfeng, no. 8, 2002, pp. 36-37.

29. Ding Guangxun, "The Paramount Issue in Church Work is to Promote Theological Reform," http://news.china-b.com/jyxw/20090420/1344710_1.html (accessed on September 12, 2009); For a close study of Ding and his theology, see Philip L. Wickeri, Reconstructing Christianity in China: K. H. Ting and the Chinese Church, Maryknoll, NY, Orbis Books

30. Ding Guangxun, "Zai zhongguo jidujiao dibaci daibiao huiyi shang de shumian jianghua" (Speech at the Eighth Meeting of the China Christian Council), Tianfeng, 2008, no. 1, p. 9.

31. Wang Aiming, "Ruhe tigao xintu de xinyang suzhi" (How to Raise the Quality of Belief), Tianfeng, no. 1, 2002, pp. 36-37. 
decades, a common expression used is "the suzhi of the Wenzhou church has improved." This expression refers to the fact that the urban middle class, particularly young and middle-aged businesspeople and college graduates, have increasingly joined the local church. The tenth anniversary special church brochure published by a major local church in 2005 states that "under the protection of God and the guidance of the Holy Spirit, the church's various ministries have developed smoothly and achieved certain outcomes and effects: the number of believers is steadily on the increase, and the quality of belief is also improving. We firmly believe the church will have a better future." This statement is representative of local believers' view of the post-Mao Protestant revival in which the rise of relatively high suzhi of believers constitutes one key dimension.

Nevertheless, this suzhi discourse reveals situations of not only widespread agreement but also intense contention within the Wenzhou church. A thoughtful young local preacher spells out the Christian notion of suzhi in an essay entitled "The crisis and challenges of today's Wenzhou church." He has frequently travelled to churches and seminaries in Hong Kong and led a Wenzhou Christian delegation of about 20 people to visit Hong Kong in 2006. After briefly describing the scene of a well-ordered Hong Kong church meeting, he started to reflect on the Wenzhou church's lack of a good institutional structure and attributes this to the problem of suzhi. As he states:

The problem of suzhi involves spiritual suzhi, moral suzhi, cultural suzhi, psychological suzhi and so on ... . a balanced life is a life with suzhi. When most Wenzhou preachers, church leaders and believers' suzhi is enhanced, the institutional problem will naturally and gradually be resolved. . In the past few decades the Wenzhou church has focused on establishing the church buildings at the expense of cultivating high suzhi people with talent and has focused on leaders' prestige and power consolidation at the expense of cultivating a new generation of church leaders. This will lead to the complete collapse of the church's ministries.

The notion of suzhi forms the basis of his sharp questioning of the unique model of Wenzhou Christian development that, according to him, emphasises quantity rather than quality. ${ }^{(40)}$ Evidently, when local Protestants talk about suzhi, it does not simply mean one's spiritual quality, a singular form of suzhi, but also entrepreneurial capacity, educational qualifications, morality, and so on. As Andrew Kipnis aptly notes, the term suzhi can take both singular and plural forms, and the slippage between the two forms enables hierarchical discourses that require linking one of the many specific qualities of an individual to an overall judgment of his/her Quality. ${ }^{(4)}$ By moving from plural to singular/overall suzhi, the young preacher's warning reflects the Wenzhou church's rising anxiety over its own status in an increasingly competitive religious environment, especially in comparison with overseas churches. ${ }^{(2)}$

Raising the church's overall suzhi has become an emergent issue on the agenda of many Wenzhou churches, particularly those led by forward-looking entrepreneurs. Brother Zhou is one of those who seek to promote the church's "cultural mission." Once he passionately spoke on his church's goal:

We should magnify (hongyang) the culture of the church. I think today's Christians all have Christian faith, but this is not enough. They still need to have a Christian culture. Christian culture has a rather big effect on promoting church growth and raising the church's overall suzhi. Our church not only needs to fulfill an evangelical mission but also a cultural mission. This cultural mission means that we need to let Christ rule in every field, be it science, art, mathematics, politics, economy, culture, or education. We are all able to uphold Christ, That is to say, the best scientist is Christian, the best educationist is Christian, the best writer is Christian, and the best mathematician is Christian. In any field we all uphold Christ. This is the cultural mission.

The term "culture" here has little to do with a way of life in the anthropological sense, but refers to one's educational attainment and levels of civility. It is a central part of the suzhi discourse, as suzhi is often interchangeable with cultural quality (wenhua suzhi) in daily Chinese rhetoric. As a successful factory boss, Zhou once even said that "suzhi determines one's fate." The Protestant emphasis on overall suzhi reveals the church's increasing focus on social outreach and cultural engagement with the larger public in order to be "the salt and light" in society. Many local Protestants, both church leaders and ordinary members, share the same logic that "as the church's suzhi rises, more people will naturally like to join it." Wenzhou Protestants' use of suzhi discourse reveals a two-

40. For the establishment and expansion of Christian space in post-Mao Wenzhou, see Nanlai Cao, "Christian Entrepreneurs and the Post-Mao State," art. cit.

41. Andrew Kipnis, "Suzhi: A Keyword Approach," art. cit., pp. 303-304.

42. For a portrait of Wenzhou Protestants' desires and practices of catching up and competing with their overseas counterparts, see Nanlai Cao, "Boss Christians," art. cit., pp. 84-85. 
way process: the secularisation of the religious and the spiritualisation of a profoundly secularised local society. Wenzhou entrepreneurial values and forms have imposed themselves upon the church, but all of this is supposedly in the service of Christianity, of spreading Wenzhou Christianity. There is also a tension and sometimes a border drawn between secular and religious values. This can be seen in people's view of piety and pious believers.

Compared with the term suzhi that keeps cropping up in local Protestants' conversations, I have noticed the relatively low frequency of the term "piety" (zhongxin) being used by local believers, even though piety is still often used to evaluate the elder generation of believers who suffered under Mao. These suffering Christians may receive the title "God's pious servants" (shen de zhongxin puren). When piety is mentioned today, it is always associated with such terms as "the Cultural Revolution," "suffering" (shouku), "martyrdom" (xundao), and "persecution" (bipo). In particular, the term "God's pious servant" most often appear in memorial speeches recalling how an individual testified to personal faith by "suffering for Lord" (wei zhu shouku) in the face of harsh persecution during the Cultural Revolution. Many elderly Wenzhou believers still wholeheartedly embrace state persecution to testify to the authenticity of their faith. As a local church leader and retired high school teacher, who was jailed for two years for his faith during the Cultural Revolution, commented, "Only persecution can attest to the truthfulness of one's faith, as it is hard to tell who is a real Christian and who is not." The Bible verse frequently invoked by the elderly suffering Christians to express this positive view of persecution and martyrdom is "Blessed are those who are persecuted because of righteousness" (Matthew 5: 11).

In fact, the current church's concern and pursuit of suzhi underscores a major shift in both its identity and its direction of development. In light of the current local government's lassie-faire attitude towards Christianity, Christian piety refers not so much to an inner quality that once helped defend personal faith against brutal repression by the Maoist state but is linked to performed humbleness and self-denunciation in the form of prolonged prayers and weeping during public worship services. Viewed increasingly as an empty form that can be performed, cultivated, and even faked, piety has become devalued.

Some elderly believers frequently say how bad (kuiqian) they are and how they are unworthy (bupei) of God's love in public, but the younger generation of believers has interpreted this routine practice as a sign of personal pride, as self-denigration or even self-denunciation during prayers can serve as a conspicuous display of self-commitment. For them, this may not be sincere expression of humility but merely a stereotyped superficial ritual formality. Of course, no one says that he or she is opposed to piety. Instead, people emphasise piety as the basis of personal gifts (enci) when they see talented individuals who are not actively involved in church, a great pity in their view. In this way they justify their conservative moral agenda. As I have observed in many circumstances, however, one's spiritual piety is not emphasised in the current context as much as it was under the harsh repression of the Maoist state.

Those who demonstrate high suzhi and capacity in dealing with church affairs are actually viewed as having innate and self-evident spiritual qualities. For example, a recently baptised local entrepreneur who made huge financial contributions to various church building projects both in and outside of Wenzhou is said in the local church community to "love the Lord ardently" (rexin aizhu), and his testimony has circulated widely in local church circles. Apparently, a multifaceted notion of Christian suzhi is celebrated in the church. Piety as an embodied Christian quality, although still quite meaningful to many of the elder generation of believers - an increasingly marginalised minority in the urban church - has been subsumed into an overall Christian suzhi.

\section{Justifying a socioreligious hierarchy}

The rhetoric used in many local believers' conversations and speeches shows that the church's marginalised subcultural identity centred on the notion of piety is being replaced by an elitist form of identity reflecting its more sophisticated, cosmopolitan pursuits in mainstream urban society. It is greatly appreciated in the Wenzhou church if one is good at leading a meeting, making a decision, dealing with state agencies, resolving a conflict, and giving a public speech Wenzhou churchgoers, both young and old, men and women, speak highly of those Christians who are in positions of social, political, and economic influence and who have high suzhi in various forms. As one put it, "The bosses have better (social) knowledge and a wider scope in the world, so others like to listen to them." Some have even engaged in discussions over who is the richest preacher and who is the biggest Christian entrepreneur in Wenzhou. Many local believers are enthusiastic admirers of overseas church brothers who hold high educational and professional credentials. Consciously using the "celebrity effect" ( $\mathrm{min}$ gren xiaoying), some local churches take pains to seek notable overseas guest preachers/speakers in order to exhibit 
grong). However, it also has much to do with the "low suzhi" of current full-time preachers. Some church members have noticed that the educational level of the average Wenzhou Protestant lags behind that of the larger society, and secular jobs often require stronger educational qualifications than the position of a preacher in the church. Almost no full-time church workers in Wenzhou hold college degrees.

Initiatives have been taken to enhance the wenhua suzhi of the local church community. Among the many church training programs in Wenzhou, the Wenzhou Lay Training Centre provides the most systematic training to help the vast number of church volunteers serve the church. ${ }^{(45)}$ Established in 1995 by the Wenzhou city-level Three-Self Patriotic Movement/ China Christian Council, the Centre offers short courses in preaching, hymn and music studies, and church management. The goal of this rather practical training is to cultivate a group of volunteer preachers "good at talking and singing" (huijiang huichang) and to "raise their Bible knowledge and preaching quality" (jiangdao suzhi $\left.{ }^{(46)}\right)$. Since most of the volunteers in Wenzhou have other jobs, a regular correspondence course was also set up with the support of the Nanjing Union Theological Seminary in the same year, and it soon became popular. Hundreds of church volunteer workers receive training from the Centre each year.

The institutionalised lay training system has greatly facilitated pastoral work in Wenzhou. However, as the local population's general educational level continually improves, many young church workers have felt pressured to further enhance their cultural quality and preaching skills, and have recently sought educational credentials not only in seminaries but also in secular higher education institutions. For instance, a significant number of Wenzhou church preachers have enrolled in part-time religious study graduate programs at Peking University and the People's University in Beijing to pursue Christian studies since 2004. ${ }^{(47)}$ The programs involve about 80 days of classroom instruction during school breaks over a two-year period. Upon successful completion of the coursework, the two prestigious Chinese universities issue graduate coursework completion certificates that enable graduates to find better positions in their churches or move on to degree studies in overseas seminaries.

Suzhi involves embodied habitus; it is not only a matter of education, or in this case, of achieving religious literacy, but also has much to do with individual tastes in cultural consumption and patterns of behaviour. ${ }^{(48)}$ During my fieldwork in Wenzhou, some local churches invited professional musicians and modern orchestras from other cities and even overseas to perform in Wenzhou before and during Christmas as
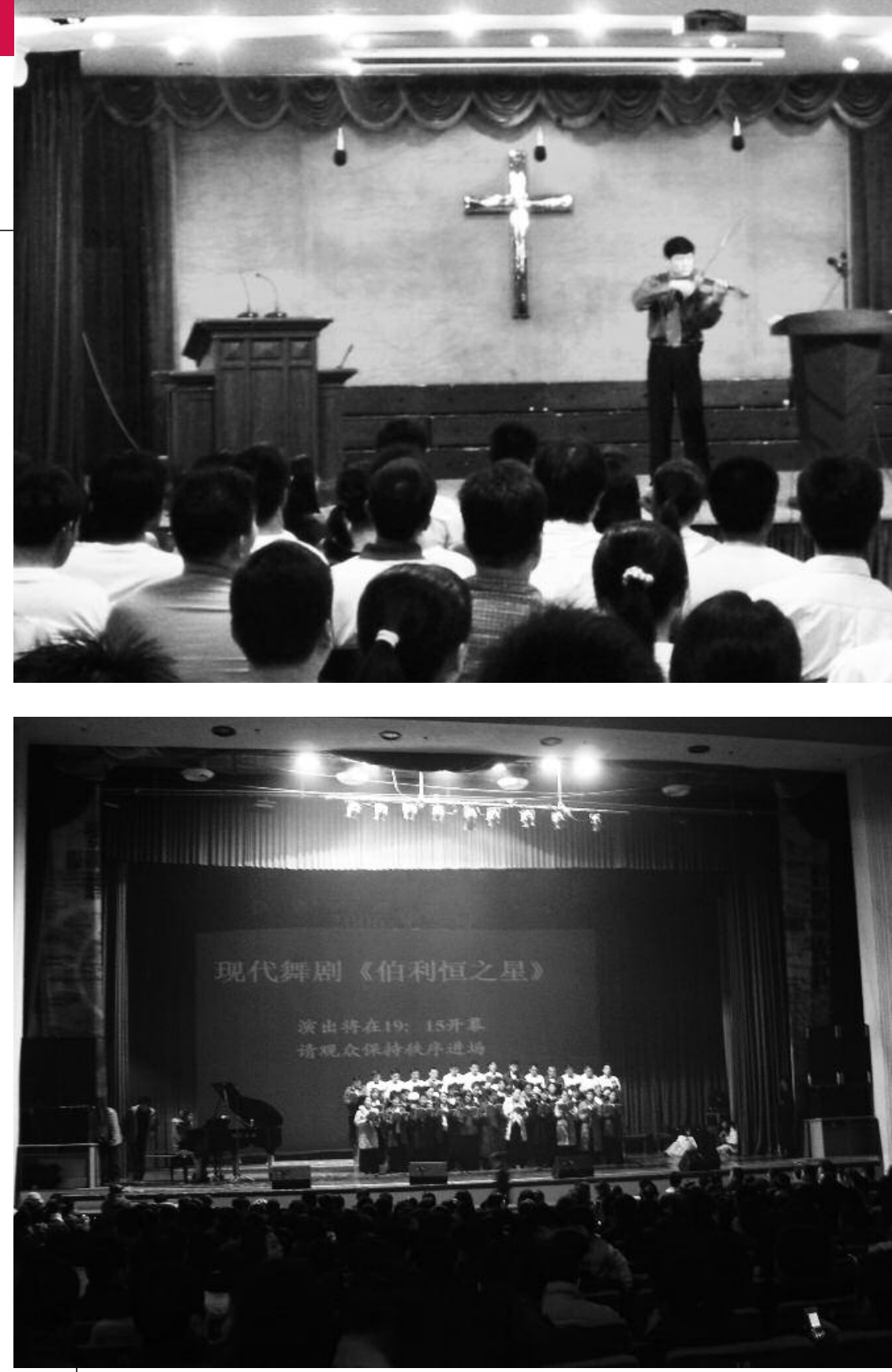

A modern dance drama entitled "The Star of Bethlehem" held in a local theatre and attended by nearly a thousand Wenzhou churchgoers. @ Nanlai Cao

a means of enhancing and displaying their wenhua suzhi. In so doing, they seek to justify their conservative faith identity in an urban commercialised economy. The habitus of these advantaged urban Protestants distinguishes them from popu-

45. A great number of overseas pastors and preachers have been involved in the training of Wenzhou's lay church leaders through a variety of courses and programs. They mostly operate secretly, since such connections with the foreign church are technically illegal in China.

46. Shi Chenghui, "Wenzhou jiaohui shi ruhe kaizhan yigong peixun gongzuo de" (How the Wenzhou church volunteers' training work is conducted), Tianfeng. no. 10. 1997, p. 9.

47. The People's University charges 10,000 yuan for its Christian Thoughts course, and Peking University 18,000 yuan for its Christian Culture course.

48. On habitus, see Pierre Bourdieu, Outline of a Theory of Practice, Trans. Richard Nice, Cambridge, Cambridge University Press, 1977. 


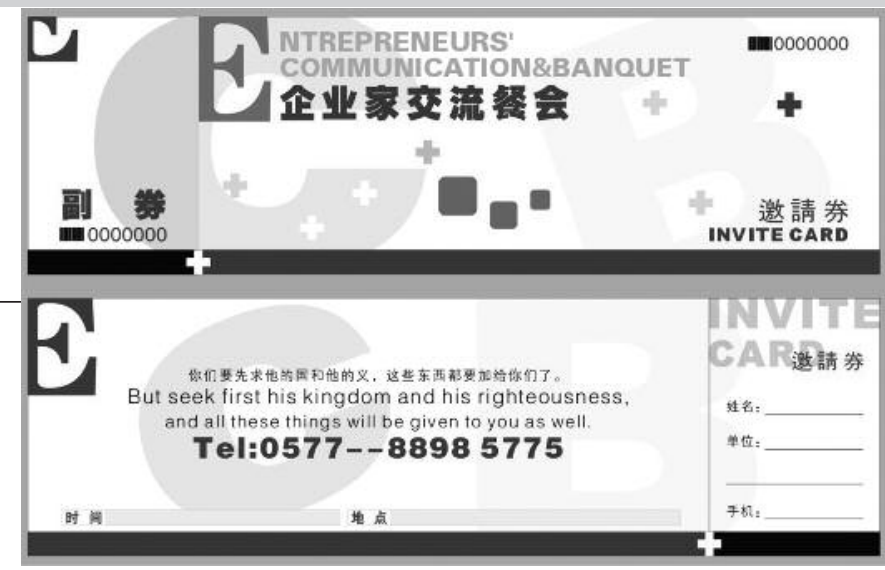

lar religious practitioners in impoverished rural communities, where amateur local opera troupes are often hired for ritual events.

This emphasis on wenhua suzhi relates directly to local entrepreneurs" acute awareness of their lack of schooling and nouveau riche status. As a boss Christian who runs a shoe factory characteristically put it, "In the past you could start your own business with 10,000 yuan; now even if you have a million you can hardly do it. Times are different now. In the past, the shoe-making bosses all had no culture and only depended on hard work. Now it is impossible without culture." The dominance of single individuals or households over most Wenzhou enterprises gives them clear lines of command and enormous flexibility. But as they grow, particularly when export-oriented production increases, they face the limits of what one person or family can manage. Bosses who have experienced ups and downs in the business world often express a deep regret for having not read the Bible earlier, for they now realise that it is all up to God (rensuan buru tiansuan). However, Christianity provides not just a sense of certainty or psychological comfort but, more importantly, a bridge, a universal canonical language, and an essential cultural quality for them to communicate with Western modernity and expand their global business network.

For successful entrepreneurs and church leaders, religious practices embody direct transferability between a textuallybased faith, entrepreneurial wealth, and an elite sense of self-identity. The common assumption is that being Christian, Western, wealthy, modern, capitalist, and of high social status should ideally all go together. Projects of selfmaking ought to cultivate all these individually-embodied spiritual and material qualities so that individuals can project a self-image that claims all of these desired qualities at once. The Wenzhou Protestant obsession with self-improvement and the production of self-interested individuals thus contributes to the formation and justification of a socioreligious hierarchy.

\section{Limits to the embrace of suzhi discourse: The clergy's dilemma}

Many Wenzhou Protestants are striving to move upward in both the economic and spiritual hierarchies. This is neatly captured by a local Christian saying, "Bosses all want to preach, while (full-time) preachers all want to do business." Not surprisingly, there are very few full-time preachers in Wenzhou; most preachers have personal businesses and serve the church on a part-time basis. For local churchgoers,

capacity in secular business dealing and enterprise management is a main indicator of one's suzhi and is closely related to one's role and status in the church. As one young boss has observed, "Those who have developed a successful business career are less interested in gaining power in the church. Only those who have no professional career will seek power and interests in the church circle to make up for their losses in the larger society."

Similarly, a church sister made the following comments when speaking of a full-time church preacher who was involved in a serious corruption scandal by embezzling perhaps hundreds of thousands of yuan in church funds: "Entrepreneurs (qiyejia) work for their enterprises, bosses (laoban) work for money, preachers (chuandaoren) work for making ends meet." She added, "The person, having served the church for too long, is unable to get a good position in society and can only drift along (hun) in the church, but still receives much respect." It seems that entrepreneurs always occupy the highest place in the social evaluation system of the church, while the full-time preachers sound more like today's typical minimum-wage workers. Preacher-church leader relations sometimes mirror manager-president relations in a corporate structure. ${ }^{(49)}$ Fulltime preachers must obey the order of the church leaders who are in charge of full-time co-workers' employment and compensation, or they will be fired.

The commonly-held belief regarding full-time preachers in the church is that those who are unable to test into a four-year college may end up attending a two-year seminary school for a devalued diploma. It is common for church brothers and sisters to question a full-time church worker behind his back, saying something like, "If he could make good money in his (secular) work, would he still serve the church on a full-time basis?" The assumption is that getting rich should take priority over commitment to church work. In fact, many suggest that some full-time church workers attempt to access money, power, and respect through the church that are otherwise unavailable to them in the larger society. This vividly captures the disadvantaged status of full-time church workers.

Church leaders are also under pressure to validate the authenticity of their faith by demonstrating high suzhi in deal-

49. Most Wenzhou churches are controlled by lay people rather than full-time preachers. For details of the Wenzhou church's lay-clergy relations and its hierarchical management structure, see Nanlai Cao, "Boss Christians," art. cit. 
ing with the secular world. As a full-time preacher commented on a Christian boss and church leader, "It's not that you have to give up your enterprise to be a full-time church worker. If he didn't run his enterprise, he would not be able to do good work in the church. With a private enterprise, the effects (of church work) are much better." The Christian boss quit his business for one year and transferred the enterprise to his relatives. However, as a rather sensitive person, he discovered that during that period, some people did not even greet him, or pretended not to recognise him in church. "Without money, no one listens to you," he says. Some church co-workers reckon that his growing confidence comes directly from his recent business success. Such comments underscore a finding that appears throughout this study: church leaders' private enterprises give them an advantage in accruing significant influence in the church and facilitating their church work. However, a church leader may still find himself in a dilemma, even if he can demonstrate his business achievements before the church. In this case, some would say that "When he was poor, he bowed his head while walking and no one listened to him; after becoming rich he stands on the stage and wants people to listen to him."

This dilemma shows that many local believers hold contradictory expectations toward the clergy. The contradictory expectations reflect the conflicting desires among the local church community that can be characterised by the tension between a prosperity gospel and a fundamentalist belief in the spiritual/secular binary. However, the seemingly contradictory categories are often well integrated with recourse to the suzhi discourse that enables one to claim both economic and spiritual superiority. Therefore, the Protestant project of self-making manifests a point of convergence at which distinctions and inequalities of economic power and social prestige are reinforced and legitimated. In sum, the growing popularity of the term suzhi among Chinese Protestants in the Reform Era points to both a change of individual mentality and a larger organisational change within the church community, from the central theme of survival amongst hardship to that of development in an openly competitive environment.

\section{Conclusion: Christian suzhi and elite Protestant religiosity}

Protestant Christianity has flourished throughout China in the last few decades of economic reform. It is particularly popular in local and regional spaces along the coast where the state established special economic zones in the early 1980s and withdrew from direct intervention in the private economy and other spheres of life thereafter. In recognition of Christianity as a source of moral values in the economy, the state has provided much greater space for the expansion of Protestant activities and structures than for the staging of popular religious events and practices, which still bear the stigma of superstition. Although the upwardly mobile class of believers discussed in this paper may remain a minority among the overall Chinese Christian population, it has increasingly assumed leadership positions and discursive power in the church, and is thus more likely than other Christian groups to shape the future of Chinese Christianity and its relationship with the state.

In a 2006 interview with a senior officer (chuzhang) at the RAB office in the Wenzhou municipal government building, I was told that Christian entrepreneurs are given official permission and blessing to set up chapels and preach in their own factories, not only as a gesture of official respect for local bosses' personal religious beliefs and entrepreneurial productivity, but also as an appreciation of Christian moral culture as an effective means of workforce discipline. This is a telling example of the convergence of the reformist state's and private entrepreneurs' neoliberal interests, despite the fact that preaching or holding religious gatherings outside of state-approved religious venues is still technically illegal. Apparently, the state discourse on spiritual civilisation has willingly incorporated Christian morals into the spiritual development of society as a necessary parallel to national progress in the material realm. Against this urban, social, and discursive background, the notion of raising the quality of belief has emerged and become central to the discourse of local church development. It provides a semiotic space in which different groups of Chinese Protestants come to engage secular modernity, articulate their interconnected, often mutually reinforcing religious and social ideals, and debate on the perceived right path for the development of the Chinese church.

This debate is certainly not confined within the institutional context of local Protestantism or relevant only to the construction of local Protestant identity. One sees the pervasiveness of the Christian suzhi discourse in the official Protestant circle and in its deep entanglement with the theological reconstruction movement on the national level. Perhaps the debate on what really constitutes the ideal Christian suzhi and how it matters will continue for the time being. Nevertheless, there appears to be a consensus among various interlocutors in the church that suzhi is essential to an elite mode of Protestant religiosity and to sound church governance in twenty-first century China. As a local Wenzhou church worker put it in a rhetorical question, "We carry such a (evangelical) mission. If 
there is no suzhi as a foundation (jichu) for church work in modern society, how can we accomplish what God has taught us to do and achieve a substantial leap forward?"

In this article I have highlighted the significance of the suzhi discourse as conducive to the construction and expression of a new elite Protestantism in China's emerging market economy as well as the politics behind the discourse. The growing elite Protestant identity has significant implications for how the church will engage both state and capitalist modernities. However, it is first and foremost a product of the Chinese church's expanding worldly engagements in the last few decades, as the Christian suzhi discourse testifies to the increasing assertion of urban middle-class consciousness within the Chinese Protestant community, rather than in Christian theology or ideology per se. What is significant and unique about the Christian suzhi discourse is its tendency to deny the unbridgeablity of any split between the material and spiritual spheres of everyday existence.

As the heavily loaded term of suzhi circulates with increasing speed both within and beyond the church, one may be tempted to believe that the place of Protestantism in a rapidly changing Chinese society will largely hinge on the rise or fall in the quality of belief. In fact, some Chinese scholars have argued that the urban church should guide the development of the rural church because the former surpasses the latter in the quality of belief. ${ }^{(50)}$ Therefore, can the emergent Christian suzhi discourse be seen as a case of a religion consciously adapting itself to the new socioeconomic milieu through secular legitimation politics, or as just an automatic manifestation of changing socioeconomic realities in the religious/spiritual domain? Further research is needed to determine the causal relationship. Either way, Chinese Protestantism has been fundamentally transformed in a reconfigured political economy. Hence, social-scientific research on contemporary Chinese Protestantism should shift its focus from the quantitative dimension of religious expansion under political repression to the qualitative aspect of religious development and innovation under new circumstances, be it cultural, moral, emotional, or aesthetic. Before attending to the aspirations, rhetoric, and actions of individual Chinese Protestants and the mechanism of the post-Mao Protestant revival, one needs to refrain from routinely assuming the Chinese Protestant experience as a homogeneous derivative of Christianisation in the West.

Western observers (especially the Protestant-minded) often assume that the post-Mao religious revival reflects a spiritual hunger and yearning among the disillusioned Chinese. Although this observation may not be completely wrong, it fails to comprehend the complex nature of contemporary
Chinese religiosities, especially the multiple social and ideological worlds of Chinese Protestantism, by projecting Western cosmology onto the cultural other. For many urban-oriented Chinese converting to and practicing Christianity in the post-Mao era, raising the quality of belief has become a paramount concern, embodying their elitist desires and pursuits when confronting radical social and economic change. Countering the one-dimensional representation of Christian religiosity, self-enterprising Chinese Protestants in prosperous coastal areas are currently using monotheistic religion to seek all desired embodied qualities as promised by the sacred text and constructing a hybrid form of socioreligious identity. Indeed, Chinese Protestant development has undergone not only a quantitative increase in church membership and religious space, but also a qualitative change in social composition, religious positioning, and cultural outlook. •

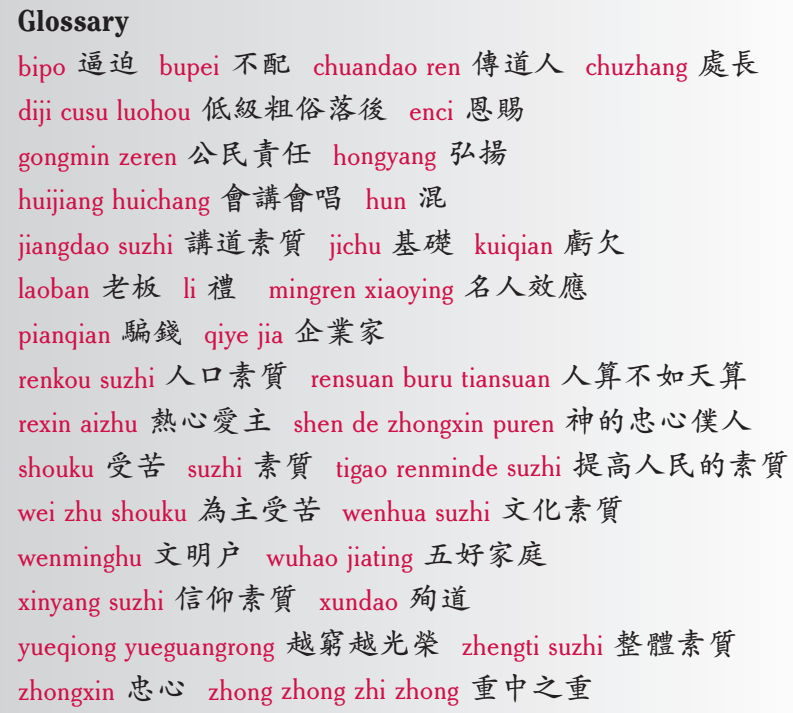

50. Chen Cunfu and Wu Yubo, "Chengshihua guocheng zhong de dangdai nongcun jidujiao," art. cit., p. 83. 